\title{
State of Affairs in ICTs Usage within the Hospitality Industry (Guest House \& Hotel) Operations: A Case of Brong Ahafo Region Ghana
}

\author{
Samuel Akyeramfo-Sam \\ Department of Computer Science \\ Sunyani Technical University \\ Sunyani, Ghana
}

\author{
Isaac Kofi Nti \\ Department of Computer Science \\ Sunyani Technical University \\ Sunyani, Ghana
}

\begin{abstract}
The impact of the hospitality industry to the total growth of the Ghanaian economy cannot be exaggerated [1, 2]. Information and Communication Technologies (ICTs) play an important part in improving competitiveness, empowering development, and bringing advancement to all stages of society [3]. The Swift and significant development of ICTs and the spreading out of the internet have moved-in in all phases of human life [4]. Hospitality Industry as one of the presently fast growing industries in Ghana and the world Writings disputes that tourism cannot advance without a support of the ICTs application [1, 5, 6, 7]. In today's world, the Hospitality Industry in Brong Ahafo Region and Ghana at large must have suitable and appropriate adoption of ICTs novelties in order to achieve a first-hand form which is satisfactory in today's contemporary business world. This study probes the usage of ICTs and its application in the Hospitality Industry (Guest house \& hotels) in the Brong Ahafo Ghana. By means of a descriptive and crosssection strategy, this study probed the nature of ICTs resources and the predominant impediments to the use of ICTs in Brong Ahafo Ghana. The outcome of the survey point out an average level of alertness of ICTs applications in the region's hospitality industry. On the other hand, low usage of ICT and employment in e-reservation and e-booking is still of a very low rate. The assumptive and strategy implications are discussed.
\end{abstract}

Keywords: ICT; tourism; Guest-House; hotels; hospitality industry; Hotel Management; Hotel ratings; Brong Ahafo

\section{INTRODUCTION}

In a constantly mutable global society, the Information and Communication Technologies (ICTs) are now part of our everyday lives and have become a key element for economic development. Within the past decade, the deployment of ICT throughout societies started with the introduction of the net [2]. In some commerce, businesses are now learning that using ICT in everyday business activities is no more an option to consider, but a requirement for survival [2]. The introduction of ICT into business radically remodelled the worldwide tourism and leisure industry, providing new development views, particularly in terms of accelerating firms and organizational competitiveness. The net contributes considerably to the distribution on the widest potential scale of data concerning the offered merchandise and services, however additionally to facilitate their selling method in the hospitality industry [7]. A Google report in 2013 reveals that the internet forms $80 \%$ as a source for information for tourists planning for a holiday and the report declared that online source of information presented a higher measure of confidence for these tourists. The internet as a source of information for most tourists emerges from the fact that the internet massively aids the dissemination of information and the information process; thus to say that most tourists (43\%) that visit online travel agency already knows precisely what services they wants and where they wish to travel to [7]. The holiday-makers knowledge has transformed more and more recently due to the fast expansion of social media, the communications and relationship between tourists and hotels have become more and more emphasized. Social Media channels such as Facebook, twitter and Instagram convey and provide more and accurate facts about tourists' consumption manners, which provides better link of the supply to market requirements. And also, the Social Media platform has provided an up-to-the-minute and latest tool for marketing, making the promotion of goods and services very effective and faster due to the speedy spread of info in the online environs. Currently it is estimated that the average rate of penetration of Social Media in the technologically advanced countries is roughly $44 \%$, while in developing states its influence is $29 \%$ [8].

Several public declarations has been made in Ghana by governments, states-officials and policy makers on how the state intends to enhance its international attractiveness and economic opulence using the hospitality industries as a central facilitator. Tourism is one of the identified major socioeconomic activities and the quickest advancing sector of the economy of Ghana. Tourism contributes nearly $16 \%$ of the overall annual foreign exchange for Ghana [9]. The hospitality industries in the Brong Ahafo Region and Ghana as a whole are vital sources of employment to most of the youth, as well as creation of new solid business prospects to offer an increase to the stream of revenue to the government of Ghana in terms of tax and improving novelty. Same views were shared by $[4,10]$ explains that tourism contributes massively to innovation, employment and entrepreneurship.

According to [5] in the context of tourist hotels, that businesses realise a viable gain by either single out products and services or offering modest charges. But, Kumar (2001) cited by [4] proposes that gust house and hotels as service providers cannot advance competitiveness as a means of delivering higher value to their clients and customers without the right adoption of ICTs. The spread and diverse tourist needs have called for hotels that focus on tourism to leverage their offerings and services over ICT in order to gain advance 
facts of their clients and customers and deliver one-stop centres by exploiting online systems and applications.

For the hospitality industry in Ghana to succeed and compete globally, the need for well-organized and quick to respond hotel subsector which integrates modern trend of customer and business service cannot be overlooked. Hospitality Industry as one of the presently fast growing industries across in Ghana and the world cannot advance minus ICTs support. In today's world, the Hospitality Industry in Brong Ahafo Region and Ghana at large must have suitable and appropriate adoption of ICTs novelties in order to achieve a first-hand form which is satisfactory in today's contemporary business world.

ICT when employed in the right form assistance and make stronger the significance of the hospitality industry to the progressively more digital sector, raise the quality of the hospitality industry, speeding up the hospitality industry service participation and the upsurge customers and client's citizenship in form of trustworthiness. Even though the appealing role of ICTs in remodelling the relations between hospitality industries and their spread market, an investigation concerning to ICTs and the hospitality industry (hotels) sector seems to have overlooked developing economies [4]. Remarkable research on ICT in the hospitality industry include, Adopting Electronic Business in Ghana: Story of the Hospitality Industry in Ghana [1], The Information and Communication Technology - Impact on the Hospitality Industry in Romania [7], ICT as A New Competitive Advantage Factor- Case of Small Transitional Hotel Sector [6] and others.

In spite of these researches, their generalisability is still not away from doubt, because emergent economies haven't been well thought-out to the point that even the nature of ICTs used in the emerging economies of which Ghana is one hospitality industries as well as their saddling challenges are still not well investigated. This has created a gap in accepting the significance and role of ICTs and its related systems and applications in the hospitality industries (tourism hotel) sector an arguable matter. In an effort to close this empirical gap, this research was planned to establish the state of affairs of hotel associated ICTs in the Brong Ahafo Region of Ghana so as to make available an academic launch pad for future research. The expressive nature of the study is because its efforts to explore the predominance and level of application of ICTs.

The hospitality industry is a new mix of business principally in Ghana. Writings disputes that tourism cannot advance without a support of the ICTs application $[1,5,6,11,7]$. Internationally, at the end of the year 2011, it was projected that above $50 \%$ of vacation trips and more than $40 \%$ of business trips are reserved online [7]. Even though ICT is a key component in the competitiveness of hotels in the tourism sector [6], slight studies has been done in developing countries [4] such as Ghana. This study was for that reason set up to establish the form and types of ICT tools employed and defies encountered by the hospitality industries (Guest houses $\&$ hotels) in the deployment of ICT.

\section{Tourism and Hospitality Industry in Ghana}

The hospitality industry in Ghana has received a significant consideration in the economic advancement strategy by various governments since the 1980s. Tourists' expenditure has seen a progressive increment and the average number of tourists have also seen increases every year, making various tourism subsectors activities expanded for both public and private. A separate ministry was established in 1993 by the Government of the republic of Ghana to emphasize their commitment to tourism development in the country called Ministry of Tourism (MoT), with help from foreign organizations like the World Tourism Organization (WTO) and United Nations Development Programme (UNDP) [1, 12]. A fifteen (15) Year development plan was proposed by MoT which was initiated in 1996 and to end in 2010. The hospitality industry in the country has contributed its quota progressively to the economy of the country, especially in recent years, between 2000 to 2005 tourist arrivals and spending shout up from $46 \%$ to $68 \%$ respectively. Incomes from tourism was estimated to reach an approximate value of $\$ 1.5$ billion by the end of 2007 [1, 13]. The country's attention is said to be progressively shifting from principal produces to a market oriented economy with prominence in the hospitality industry and tourism in general. One can say the cultural, intellectual potential and economy of a country is directly linked the hospitality industry of the said country [1], hence this industry must be managed correctly and efficiently to meet intercontinental standards in order to appreciate the full profits and benefits that the industry offers.

\subsection{Information \& Communication Technology (ICT)}

A universally acknowledged definition of ICT has not been established, because the theories, procedures and applications involved are frequently changing on an everyday basis [4] Some researchers' defines Information and Communications Technology (ICT) as a system that comprises the usage of computer hardware, telecommunication and software devices for accumulation, transform, and control, protect, transmit and take delivery of data or information $[1,4,11,14]$. ICTs are has become an important part of the business core. These days, employing ICTs is no more a distinctive, typical by itself. Only a resourceful and effective use of ICT enables establishments and individuals increase competitive benefits $[15,4]$.

Looking at the above definition of ICTs by $[1,4,14]$, one can say that the term ICT involves electronic info-processing technologies such as the internet and computers, smartphones, fixed telecommunications line and other wireless communication device, broadband, networks and various smart and intelligent application equipment stretching from braille readers and barcode scanners. Some electronic, electrical and mechanical machines do have ICT embedded to enhance its functionality.

\subsection{ICT and Hospitality Industry}

Tourism defined by Holloway (2004) cited by [4] is the business which involves the provision for diverse types of visitors; rapid, overnight or elongated stay and daytime visitors comprising car-parking, accommodation, attractions and show biz, food and beverage. Tourism includes activities such as traveling to and remaining in places outside their usual environment or home not exceeding one uninterrupted year for business, leisure or other purposes. In the ancient days, people do call or write directly to the hotel or access a hotel via travelling agents to book a hotel room or make a reservation. On the other hand, with the introduction of ICT, 
the above approaches are considered slow and expensive. Writing and posting to the hotel involves a lot of time as with olden days 'snail mail' [11].

The coming of ICTs has modernised room reservation in hotels, now a person can make room reservation from online at anywhere at any-time so long as an electronic device with internet connectivity is available, thanks to the advancement of ICTs. The existing studies on ICTs and competitiveness deliberate numerous variables that define the diverse approaches of hotel firms to ICTs and its implementation. These factors include the size of the firm, classification, structure of ownership and type of governance employed, type of management model employed by the hotel, culture, contracts, tourism destination kinds and others [6]. It is reported that big hotel chains were more rapidly to move to ICT alliances as early as the 1980 s, however self-dependent hoteliers have been more averse regarding ICT, partially due to technophobia [6].

Information Communication and Technology as a tool for tourism permits users and clients to partake in a fast moving world activity and various works are progressively transformed through access to varied and developing technologies. ICT has become a technology's version of economical increment to stratify the necessities and wants of community over-time [4]. In a tourism viewpoint, ICTs have been implemented in tourism from the time when the early adoption of Computer Reservation System (CRS) in commercial airline in the 1950s and in the revolution to Global Distribution Systems (GDSs) in the1980s [5]

\subsection{ICT as a Competitive Advantage Strategy in Hotels \& Guest Houses}

A report by [5] indicates that a well-managed ICTs system aids in gaining a competitive benefit by either upholding price control in the market or by setting apart products and services. According to [3] ICTs brings efficiency increases, access to goods and productivity, services, info and markets. Hence the strategic implementation of ICTs and internet services is critical for all business, companies and organizations trying to survive in this highly competitive environment [10]. To researchers like [4] ICTs impacts, permits hotels to reach out to international audiences. Governments and Tourist Cottages and hotels across the globe keep up stylish websites and promote their exclusive features, booking and reservation handling and promoting specials to possible guests.

The introduction of ICTs into guest house and hotel operation has the ability to bring advancement and increment in productivity of hotels at reduced cost and also raised the information quality to managers for better decision making. It adds to tourist allure around the continent. In today's globalization, individuals wish and want to locate the suitable tourist environment and destinations, booking and purchasing air company tickets, check-in and receiving boarding passes at the comfort of the their home or offices. All these can be achieved perfectly with the help of ICT.

\subsection{Research Study Area and its tourist sites}

Figure 1, shows the map of Ghana indicating the Brong Ahafo (BA) Region. The Region has 19 administrative districts, with District Chief Executives (DCEs) as the political heads. The DCEs are assisted by District Coordinating Directors (DCDs) who are responsible for the day to day running of the districts. The DCEs work under the Regional Minister (the political head of the region), while the DCDs are under the Regional Coordinating Director. Sunyani is the administrative headquarters of the region, where the Regional Minister resides. The legislative wing of the District Assembly. One third of its membership is appointed by the Government in consultation with local leaders, while the remaining are elected on non-party lines. The District Assembly elects its own Presiding Member. The District Assemblies are divided into Town and Area Councils, depending on the population and land area of the district. A compact settlement or town with a population of 5,000 or more qualifies to have a Town Council status. An Area Council is made up of 2 or more towns which, when pulled together has a population of 5,000 or more. The region has 37 Town Councils and 106 Area Councils. Eight of the districts bears the name of the district capital, with the remaining five (Asunafo, Asutifi, Tano, Jaman and Sene) named after geographical landmarks or historical events. The Region measure 39,557 square kilometres and it's the 2nd largest region in the Ghana (16.6\%) and parts boundaries with the Ashanti and Western Regions to the south, the Northern Region to the north, the Volta Region to the east, the Eastern Region to the southeast and La Cote D'Ivoire to the west. The central point of the landmass of Ghana is in the region, at Kintampo. The ecosystem of the region has brought about a lot of tourist attractions. The Pumpum River falls 70 metres down some beautiful rocky steps to form the Kintampo Falls, as it continues its journey towards the Black Volta. The Fuller Falls, 7 kilometres west of Kintampo, (the centre point of the country), also provides a scenic beauty as River Oyoko gently flows over a series of cascades towards the Black Volta. Another scenic site is the River Tano Pool which houses sacred fish that are jealously protected by the local community who live along the river near Techiman. There is also a pool on the Atweredaa River, which runs through the Techiman market. The Buabeng-Fiema Monkey sanctuary, located 22 kilometres north of Nkoranza [16].

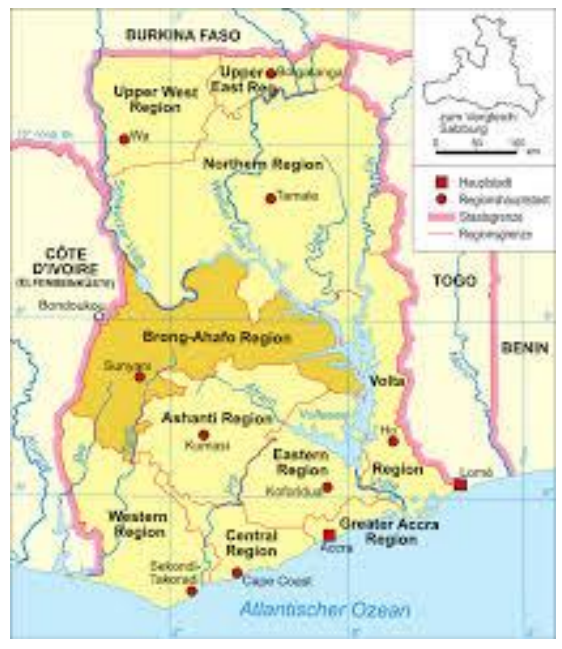

Figure 1 Map of Ghana (Showing Brong Ahafo)

\section{METHODOLOGY}

The research was conducted via a questionnaire survey amongst hotels and guest house in Brong Ahofo Region of Ghana, 125 hotels and guest houses of diverse grades and size are located in various districts of the Region. The 
questionnaire was given directly to heads of IT head, managing directors (MDs) and Receptionist of the various guest houses and hotels. The MDs were carefully chosen for this research because they hold a broader overview of how their various guest houses and hotels are responding to ICT in the hotel industries, most importantly. They are typically in charge for strategic improvement of the guest house and hotel, including the placement of ICT with business strategy. The units of analysis for this research were guest house and hotels, which were legally registered and licensed and by Ghana Tourism Authority (GTA).

Stratified sampling was used to group the guest house and hotels in the Region into Eight (8) geographical divisions, namely; Kintampo North Municipal, Asunafo North Municipal, Berekum Municipal, Wenchi Municipal, Sunyani Municipal, Dormaa Central Municipal, Nkoranza South Municipal and Techiman Municipal. Out of 125 registered guest houses and hotels situated in BA, 90 hotels were carefully chosen proportionately according to the number of guest house and hotels in each municipality as follows; Eight guest house and hotels in Kintampo North Municipal representing $8.89 \%$, Four Guest house in Asunafo North Municipal representing $4.44 \%$, six guest house and hotels in Berekum signifying $6.67 \%$, Four Guest house in Wenchi Municipal representing $4.44 \%$, Thirty-Three (33) Sunyani Municipal representing 55\%, five Guest house in Dormaa Central Municipal representing 5.55\%, six guest house and hotel in Nkoranza South Municipal and twenty-four hotels and guest house in Techiman Municipal. Diverse classes of guest house and hotels were carefully selected to evade the preconceived notion of smallness and/or client similarity. This diverse nature of guest house and hotels and custom permitted the research to acquire a balanced opinion of ICTs usage in the selected firms. The vital point of investigation were the nature and availability of ICT facilities the Region, ICT usage prioritization and difficulties encountered in make use of ICT facilities. These features were selected on purpose since they affect the diffusion of ICT in various sectors. Data was collected using questionnaires and analysed using Microsoft Excel and SPSS and outcomes are presented in statistical tables.

\section{RESULTS AND DISCUSSIONS}

The result and discussion of the study is presented in this section.

\subsection{Hotel Grade and Size}

Guest house and hotels grades were determined in relation to the number of stars the hotel has attained which intend determines the type of amenities and facilities in the guest house or hotel.

\section{Table 1 Hotels Grade in the Region}

\begin{tabular}{|l|l|}
\hline Star Rating & Hotel Number \\
\hline 1 Star & 19 \\
\hline $\mathbf{2}$ Star & 19 \\
\hline 3 Star & 7 \\
\hline $\mathbf{4}$ Star & 0 \\
\hline $\mathbf{5}$ Star & 0 \\
\hline
\end{tabular}

\subsection{Description of Respondent}

In the selected guest houses and hotels four (4) questionnaires were given out; 1 for manager, 1 for IT head and 2 for staff/receptionist in all 360 questionnaires were distributed. Out of 360 questionnaires distributed to the 90 guest houses and hotels, a total of 280 were received back. Out of the 280 received, 213 were successfully answered correctly while 67 were null and void. The breakdown of the 213 questionnaire successfully answered is as shown in figure 2 .

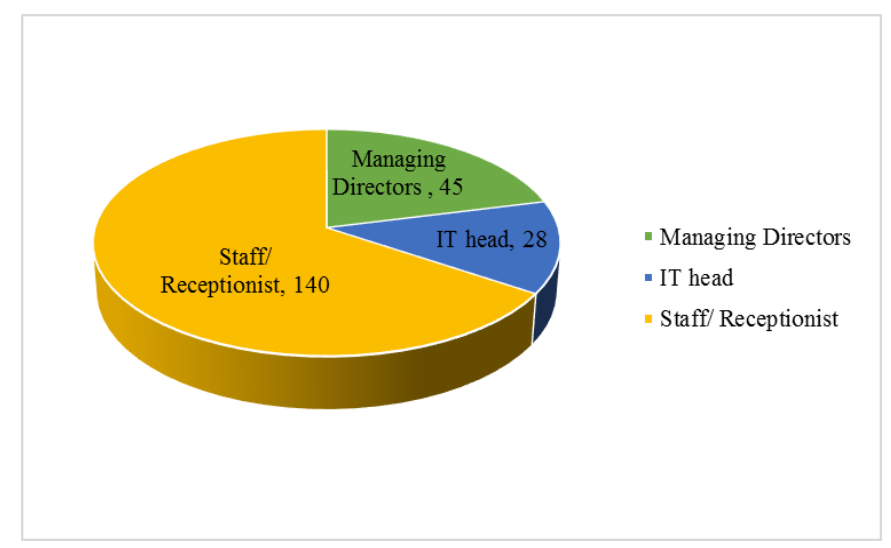

Figure 2 Field Data 2016

A low response 45 out of 90 from top management of was as a results that most of the managing directors were too busy to respond to us on our visit and some were not ready to attend to something that would not bring return to organization or them. Some of the guest houses and hotels had no IT/ICT department and IT/ICT personnel to respond to us, this resulted in the 28 out 90 turn out in the IT head response. A total of 190 respondents were expected from receptionist and other hotel staff but some hotels and guest houses only gave one responses instead of the two requested, hence resulting in 140 respondents in the staff/receptionist category.

\subsection{Respondent Age and Gender}

For gender analysis of the respondents, majority of the respondents 118 out of the 213 were males representing $55.4 \%$ whiles 95 were females representing $44.6 \%$. As for age, the majority group were in the 25-35 group while the smallest amount age group were those aged fifty years and beyond. Looking at how new ICT applications are in Ghana's guest house and hotel sector, the age category that had the highest in the sector's enlistment appears to be marginally ahead of the sophisticated versions of ICT. For example respondents with age thirty-one and above represented $68 \%$. This might mean that they are still at ease with old way or record keeping and technology and hence adjusting to new technologies makes them uncomfortable.

\subsection{ICT Facilities Usage}

One of the key objectives of this research was to investigate the nature of ICT facilities used by guest house and hotels in Brong Ahafo Region of Ghana. Figure 3, shows in usage of ICT facilities in the 45 management response. From figure 3, the most used ICT set-up is CCTV cameras, 35 out of 45 had these ICT equipment in place, followed by Intercom, which in 24 out of 45 . From the chart in figure 3 it without question 
that the guest house and hotel in Brong Ahafo Region are not making use of ICT amenities.

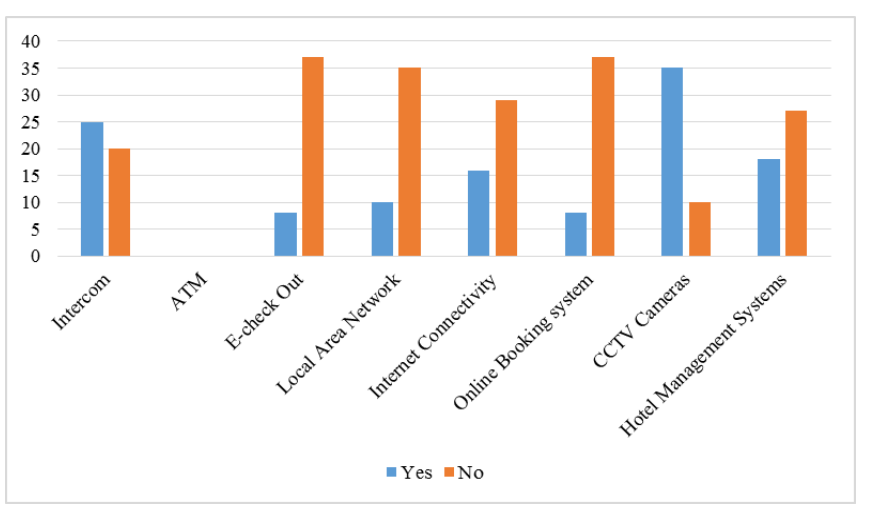

Figure 3 ICT facilities usage in the in select guest houses and hotels

It was recognised that CCTV Cameras and telephone applications were more accessible with each having. Banking services (ATM), Internet Connectivity and Online Booking were less available. The least used was E-check Out which was very rare in most guest houses and hotels. This shows that the ICT applications in the Region guest houses and hotels are not up-to-date to international standards of offering an allinclusive guest house and hotel service platform that is selfcontained and can facilitate a full service offering. This may flag the competiveness of these guest houses and hotels particularly with the higher class of tourists and other visitors that might wish to perform transaction that requires ICT such as online purchases and checking of mails in the rooms without moving out to search for ICT facilities around.

\begin{tabular}{|l|l|l|}
\hline \multicolumn{1}{|c}{ ICT Challenges } & Mean & $\begin{array}{c}\text { Std. } \\
\text { Deviation }\end{array}$ \\
\hline Outdated ICT Tools & 2.21 & 0.617 \\
\hline System Failure & 2.25 & 0.696 \\
\hline Un Skilled Labour & 3.45 & 1.041 \\
\hline Low Internet Speed & 4.01 & 0.918 \\
\hline Un Reliable Power & 3.85 & 1.271 \\
\hline Unreliable Service Providers & 3.49 & 1.149 \\
\hline Very Costly & 3.68 & 1.271 \\
\hline $\begin{array}{l}\text { Unreliable Out Sourcing } \\
\text { Personnel }\end{array}$ & 2.37 & 0.823 \\
\hline
\end{tabular}

$5=$ Very prevalent, $4=$ Prevalent $3=$ Less prevalent,

$2=$ Sometimes prevalent, $1=$ not sure

Table 1 shows the challenges faced by guest houses and hotels in the Region in the implementation and usage of ICT applications and systems.

From table the outcome of low internet speed is seen to be a predominant worry and appears that almost everyone is affected because of a low standard deviation. Other problems face the usage and implementation are high cost of ICT tools,
System Failure and Unstable electricity. Looking back at the level of education, it becomes evident that some of these hotels have heavily invested in the tools but their main challenge is lack of the organizational desire to diffuse the technology especially at operational level. Comparing outdated ICT tools to the low level of internet speed might indicate that either the guest house and hotel managers but low-priced used tools for purposes of feeling that they are part of the responsibility to use them. But due to the outdated state of the ICT tools, they might become inefficiency and sometime unproductive by failing to become well-matched with contemporary servers used by the targeted markets. Related cases of ICTs challenges were reported to prevail in some African countries [4] particularly lack of capacity of locals to operate imported ICTs to suit their local conditions and situations.

The study realised that addressing the challenge of staff know-hows in the application of the ICTs tools in these guest house and hotels will alleviate other ICTs challenges of the form system failure and unreliable outsourced ICTs staff. Other researchers also established in their studies that lack of ICT education contributes to the bad factors in ICT adaptation. They observed that slow internet connectivity and band coverage were also obstacles $[4,17]$.

\section{CONCLUSIONS AND RECOMMENDATIONS}

This study presents insights about the state of ICTs in the Brong Ahafo Region of Ghana. Notwithstanding its descriptive nature, the study tries to ascertain some of the vital features that the hospitality industry (hotel) sector in Brong Ahafo Region utilises ICT tools. This of course throws more light on the business opportunities for individuals engaged in the supply chain and also identifying the idle and unexploited technologies such as destination management systems.

\section{The conclusions are as follows:}

$\checkmark \quad$ ICTs role in promoting competitive advantage, the study focused on establishing the degree to which gust house and hotels engages ICT usage to aiding their operations. It was recognised that $35 \%$ of the guest houses and hotels owners looks at ICT as very important while 50\% just regard it as important. Meanwhile, $15 \%$ did not see any need for ICTs applications in their setups or operations. Even though the prioritization of ICT seemed to be somehow good, the implementation, application and commitment to the use of ICT and its applications was low. As a result, the nature of ICT tools is of importance to contemplate while analysing its prioritization. For instance, most of the people tend to think that ICTs is just about having some computers with internet connectivity. However, ICTs goes further than that to comprise business operations structures with technology applications.

$\checkmark \quad$ The results revealed a significant low utilization of ICT in the area of Internet Connectivity, Online Booking, Banking services (ATM), and E-check Out and about $20 \%$ had websites. But again the question of how often do they use and update the websites raises a big concern. 
$\checkmark \quad$ The study established there exit a low rate of distribution of ICTs applications related to the guest house and hotel marketing sector. This might be due to lack of sufficient alertness and training about these ICTs tools. When one examines the staffs' nature particularly persons in the IT departments, their over-all level of education is low. This might hinder or reduce intellectual networks of such staffs.

\section{The recommendations are as follows:}

$\checkmark \quad$ The study recommend that guest house and hotel sector investors to do incorporate ICT in their determinations to advance service quality so as to make stronger the loyalty of their customers whilst building an remarkable image and accessibility in reaching out to their potential clienteles.

$\checkmark \quad$ With the coming of smart and intelligent smart phones and the availability mobile applications including the hospitality mobile apps for real time communication, there is an important need for the software developers in Ghana to look further than the usage of desktop computers as the only applicable ICTs tools.

$\checkmark \quad$ Also to at least minimize or avoid the difficulties associated with unreliable electricity, there is need by the guest house and hotel operates to embrace current mobile ICTs technologies.

$\checkmark \quad$ ICT applications high cost and unreliable power were among the main established challenges in running ICTs tools and systems. This seems to be an outside threat to the advancement of ICTs. In respect to this we appeal to authorities such as the government in conjunction with NEDCo (Northern Electricity Department (NED) of the VRA) to improve the voltage and dependability of power supply.

\section{FEATURE WORKS}

The objective of this research was to establish the nature of ICT usage and distribution. Due to some degree of resources in terms of finances and time, the survey was made only for Brong Ahafo Regeion of Ghana. Hence there is a need conduct a study across other regions so as to get a better and complete view of the state of affairs. This will advance the establishment of a wide-ranging viewpoint to easily guide policy and the specialists on exactly how to advance the usage and diffusion of ICT in the guest house and hotel sector for better competitiveness. Further research should consider assessing the degree to which the integration of ICT can bring improvement in diverse areas of business such marketaccessibility, operational efficacy, market desirability and loyalty of customer.

\section{ACKNOWLEDGMENTS}

Our thanks and praise to almighty God and all staff members of STU Computer Science department for their various contribution towards this paper and to all Hotels and Guest houses in the Brong Ahafo Regieon that contributed to this study by responding to our questionnaires, we say God bless you.

\section{REFERENCES}

[1] N. Y. Asabere, V. Doku, K.-S. Simonov and D. Oppong, "Adopting Electronic Business in Ghana: Story of the Hospitality Industry," International Journal of Computer Applications, vol. 85, no. 4, pp. 1-9, 2015.

[2] I. Issahaku, "Adoption of E-Business in the Hospitality Industry in Ghana-A Case Study of Hotels," MSc thesis, KNUST Kumasi-Ghana, 2012.

[3] S. Dutta, T. Geiger and B. Lanvin, "The Global Information Technology Report 2015: ICTs for Inclusive Growth," World Economic Forum and INSEAD, Geneva, 2015.

[4] I. S. Salim, H. Shayo, E. Abaho and M. A. Sheikh, "State of affairs in ICT usage within tourist hotel operations: A case of Zanzibar," Journal of Research in International Business and Management, vol. 3, no. 6, pp. 180-187, 2013.

[5] X. Jennifer, B. Dimitrios and S. Haiyan, "Information J.," Informat. Manage, vol. 23, no. 6, pp. 451-467, 2003.

[6] M. Tanja and B. Dimitrios, "ICT as A New Competitive Advantage Factor - Case of Small Transitional Hotel Sector," Economic And Business Review, vol. 15, no. 1, pp. 33- 56, 2013.

[7] D. Firoiu and A.-G. Croitoru, "The Information and Communication Technology - Impact On the Hospitality Industry in Romania," ECOFORUM, vol. 4, no. 1(6), pp. 3237,2015 .

[8] D. Koutroumanis, "Technology's Effect on Hotels and Restaurants: Building a Strategic Competitive Advantage," Journal of Applied Business and Economics, vol. 12, 2011.

[9] R. Hinson and R. Boateng, "Perceived Benefits and Management Commitment to E-Business Usage in Selected Ghanaian Tourism Firms," EJISDC, vol. 31, no. 5, pp. 1-18, 2007.

[10] Y. Yuan, U. Gretzel and Fesenmaier, "The Role of Information Technology Use in American Convention and Visitors Bureaus.," Tourism Management, vol. 27, no. 2, pp. 326-341, 2006.

[11] I. Nwakanma, E. Ubani, B. Asiegbu and O. Nwokonkwo, "Factors Affecting the Adoption of ICT in the Hospi t ality Industry in Imo State," International Journal of Computer Science (IJCSI), vol. 11, no. 4, pp. 170-181, 2014.

[12] V. Teye, " Tourism Development Experience in Ghana," DPMN Bulletin, vol. 7, no. 1, pp. 8-12, 2000. 
[13] BoG, "A Report on the Tourism Industry and the Ghanaian Economy, Research Department, Bank of Ghana," May 2007. [Online]. Available: http://www.bog.gov.gh/privatecontent/Research/Research\%20 Papers/tourism.pdf. [Accessed 16 December 2016].

[14] N. Olifer and V. Olifer, Computer Networks, Principles, Technologies and Protocol for Network Design, England: John Wiley and Sons Ltd, 2006.

[15] R. Baggio, "Information and Communication Technologies in the Hospitality Industry: the Italian Case," eReview of Tourism Research (eRTR), vol. 2, no. 5, pp. 108114, 2004.

[16] ghana.gov.gh, "About-ghana Regions Brong-Ahafo," 2008. [Online]. Available: http://www.ghana.gov.gh/index.php/aboutghana/regions/brong-ahafo. [Accessed 16 March 2016].

[17] N. Kasim and P. Ern, "The Awareness of ICT Implementation," International Journal of Computer and Communication Technology, vol. 2, no. 1, pp. 412-432, 2010. 